Acta Protozool. (2020) 59: 107-120 www.ejournals.eu/Acta-Protozoologica doi:10.4467/16890027AP.20.009.13264 PROTOZOOLOGICA

\title{
Analysis of Water-Soluble Proteins by Two-Dimensional Electrophoresis in the Encystment Process of Colpoda cucullus Nag-1 and Cytoskeletal Dynamics
}

\author{
Yoichiro SOGAME ${ }^{1,2}$, Katsuhiko KOJIMA ${ }^{3}$, Toshikazu TAKESHITA ${ }^{3}$, Shiho KIKUCHI ${ }^{1}$, Yuto \\ SHIMADA ${ }^{1}$, Rikiya NAKAMURA ${ }^{1,5}$, Mikihiko ARIKAWA ${ }^{4}$, Seiji MIYATA ${ }^{6}$, Eiji KINOSHITA ${ }^{7}$, \\ Futoshi SUIZU ${ }^{8}$, Tatsuomi MATSUOKA ${ }^{4}$ \\ ${ }^{1}$ Department of Biological Science, Faculty of Science, Kochi University, Kochi 780-8520, Japan \\ ${ }^{2}$ Department of Applied Chemistry \& Biochemistry, National Institute of Technology, Fukushima College, Iwaki, Fukushima, 970- \\ 8034, Japan \\ ${ }^{3}$ Department of Microbiology and Immunology, Shinshu University School of Medicine, 3-1-1 Asahi, Matsumoto, Nagano 390-8621, \\ Japan \\ ${ }^{4}$ Department of Biological Science, Faculty of Science and Technology, Kochi University, Kochi 780-8520, Japan \\ ${ }^{5}$ Chikazawa Paper Co., Ltd., Japan \\ ${ }^{6}$ Department of Applied Biology, Kyoto Institute of Technology, Kyoto 606-8585, Japan \\ ${ }^{7}$ Department of Functional Molecular Science, Graduate School of Biomedical Sciences, Hiroshima University, Kasumi 1-2-3, \\ Hiroshima 734-8553, Japan \\ ${ }^{8}$ Division of Cancer Biology, Institute for Genetic Medicine, Hokkaido University, Sapporo 060-0815, Japan
}

\begin{abstract}
Assays of protein contained in water-soluble fraction of encysting cells Colpoda cucullus Nag-1 by two-dimensional electrophoresis (2-D PAGE) and mass spectrometry (MS) revealed that the amount of $\beta$-tubulin abruptly increased in $2.5-10 \mathrm{~h}$ after encystment induction. Judging from the results that total $\alpha$-tubulin content did not decrease much until $12 \mathrm{~h}$ after encystment induction, the result indicates that disassembly of microtubules may occur soon after encystment is induced. Therefore, we tried to visualize dynamics of microtubules. Immunofluorescence microscopy using anti- $\alpha$-tubulin antibody indicated that disassembly of axonemal microtubules of cilia became within $1.5 \mathrm{~h}$ after encystment induction, and resorbed in 3 days. Although the cytoplasmic microtubules failed to be visualized clearly, encystmentdependent globulation of cells was promoted by taxol, an inhibitor of disassembly of microtubules. It is possible that a temporary formation of cytoplasmic microtubules may be involved in cell globulation.

The phosphorylation level of actin $(43 \mathrm{kDa})$ became slightly elevated just after encystment induction. Lepidosomes, the sticky small globes surrounding encysting cells, were vividly stained with Acti-stain 555 phalloidin, suggesting that 43-kDa actin or its homologues may be contained in lepidosomes.
\end{abstract}

Keywords: resting cyst formation, microtubules, actin, lepidosomes, resorption of cilia.

Address for correspondence: Tatsuomi Matsuoka: Department of Biological Science, Faculty of Science and Technology, Kochi University, Kochi 780-8520, Japan; E-mail: tmatsuok@kochi-u.ac.jp. Futoshi Suizu: Division of Cancer Biology, Institute for Genetic Medicine, Hokkaido University, Sapporo 060-0815, Japan; E-mail: f_suizu@igm.hokudai.ac.jp 


\section{INTRODUCTION}

Vegetative forms of soil ciliates such as Colpoda promptly transform into a resting cyst resistant to desiccation, freezing, high temperature, acid and ultraviolet (UV) light before the water puddles dry out (Taylor and Strickland 1936, Maeda et al. 2005, Müller et al. 2010, Sogame et al. 2011a, Matsuoka et al. 2017). Encystment of Colpoda cucullus Nag-1 (Funadani et al. 2016) (18S ribosomal RNA gene: GenBank Accession No. AB918716) can be induced by suspending vegetative cells at a high cell density in $\mathrm{Ca}^{2+}$-containing surrounding medium (encystment induction by $\mathrm{Ca}^{2+}$ /overpopulation) (Matsuoka et al. 2009, Sogame and Matsuoka 2013). When C. cucullus Nag-1 is induced to encyst, mucus is expelled into the extracellular space, followed by extrusion of small globules called lepidosomes (Foissner et al. 2011) which form a mucous/lepidosome layer (Funatani et al. 2010, Funadani et al. 2016). The cells are rounded and then surrounded by a single rigid layer (ectocyst layer) 2-4 h after encystment induction, which is formed between the mucus/lepidosome layer and plasma membrane. Thereafter, the precursor substance of endocyst layers is excreted between the ectocyst layer and plasma membrane to form the firstsynthesized endocyst (4-6 h after encystment induction). The endocyst precursor is expelled periodically, resulting in the formation of several layers of endocysts (Funatani et al. 2010).

We previously proposed that the intracellular signaling pathway leading to encystment of C. cucullus Nag1 was activated by $\mathrm{Ca}^{2+} /$ calmodulin (Matsuoka et al. 2009), followed by an increase in intracellular cAMP concentration (Asami et al. 2010, Sogame et al. 2011b). This increase induces an elevation in the phosphorylation level of several proteins (ribosomal P0 protein, ribosomal S5 protein, actin, histone H4, Rieske iron-sulfur protein; Sogame et al. 2014a). Thereafter, the signaling pathways for encystment were extensively elucidated by Colpoda aspera transcriptome analysis performed by Jiang et al. (2019); in the signaling pathways activated by $\mathrm{Ca}^{2+} /$ calmodulin, the expression of genes for AMP-activated protein kinase (AMPK), eukaryotic elongation factor-2 kinase (eEF2K), AKT and several genes for autophagy are upregulated. Transcriptomic analysis of encysting Pseudourostyla also proposed the outline of signaling pathways for encystment including $\mathrm{Ca}^{2+} /$ calmodulin signaling pathways (Pan et al. 2019).

In encystment-induced $C$. cucullus Nag-1 cells, the abundance of total cell mRNA begins to drop in $1 \mathrm{~h}$ to reach minimum steady-state level (25\% of initial level) at $5 \mathrm{~h}$, and followed by a decrease in the amount of most proteins (except for proteins that are specifically expressed during encystment process). The amount of total proteins begins to decrease in $5 \mathrm{~h}$ to reach a minimum steady-state level (less than $20 \%$ of initial level) in several days after the start of encystment induction (Sogame et al. 2014b). On the other hand, the amount of some proteins, such as elongation fator- $1 \alpha$, ATP synthase $\beta$ chain, heat shock protein 60 or $\alpha$-tubulin, suddenly increases or decreases within several hours after onset of encystment induction, and thus these proteins may play important roles in the encystment process (Sogame et al. 2012, 2014b).

Two-dimensional polyacrylamide gel electrophoresis (2-D PAGE) of water-insoluble components of encysting C. cucullus Nag-1 showed that $\alpha$-tubulin content was drastically reduced within several hours after onset of encystment induction (Sogame et al. 2014b). Based on this result, we speculated that $\alpha$-tubulin gene expression might be downregulated (Sogame et al. 2014b). This speculation may be wrong, because in the present study, we found that the total amount of $\alpha$-tubulin (a sum of water-soluble and water-insoluble $\alpha$-tubulin) in encysting Colpoda does not decrease quickly. The present study showed that the reduction of $\alpha$-tubulin in the water-insoluble fraction reflected the disassembly of microtubules. In addition, we attempted to visualize the encystment-dependent dynamics of microtubules and actin filaments.

\section{MATERIALS AND METHODS}

\section{Cell culture and encystment induction}

C. cucullus Nag-1 (Funadani et al. 2016) (18S ribosomal RNA gene: GenBank Accession No. AB918716) was cultured in a $0.05 \%$ $(\mathrm{w} / \mathrm{v})$ infusion of dried wheat leaves. Colpoda cells cultured for 1-2 days were washed in $1 \mathrm{mM}$ Tris- $\mathrm{HCl}(\mathrm{pH}$ 7.2) by centrifugation $(1500 \times \mathrm{g}$ for $2 \mathrm{~min})$. The resting cyst formation (encystment) was induced by suspending the vegetative cells in an encystment-inducing medium containing $1 \mathrm{mM}$ Tris- $\mathrm{HCl}(\mathrm{pH} 7.2)$ and $0.1 \mathrm{mM} \mathrm{CaCl}_{2}$ at a high cell density $(>30,000$ cells $/ \mathrm{ml})$. As a control, the cells were suspended in $1 \mathrm{mM}$ Tris- $\mathrm{HCl}(\mathrm{pH} 7.2)$ at a low cell density $(<2,000$ cells $/ \mathrm{ml})$.

\section{Inhibitors}

Taxol (Ta; Sigma-Aldrich, Tokyo), an inhibitor of disassembly of microtubules, and cytochalasin B (CB; Fujifilm Wako Pure Chemical Corp., Osaka, Japan), an actin polymerization inhibitor, were dissolved in dimethyl sulfoxide (DMSO) to give $1 \mathrm{mM}$ stock 
solutions. Stock solutions were diluted 100 times with encystmentinducing medium (final concentrations: $10 \mu \mathrm{M}$ Ta and CB containing $1 \%$ DMSO each).

\section{Cell fractionation}

In order to disrupt the cellular structure, cells at different encystment stages were frozen for more than $1 \mathrm{~h}$ at $-80^{\circ} \mathrm{C}$, and subsequently thawed at room temperature. To obtain the water-soluble components (supernatant), samples were centrifuged $(8,000 \times \mathrm{g}$ for $3 \mathrm{~min})$.

\section{Sodium dodecyl sulfate-polyacrylamide gel electro- phoresis (SDS-PAGE)}

The cells were disrupted in the SDS-PAGE sample buffer $[1 \%$ (w/v) SDS, $30 \mathrm{mM}$ Tris-HCl, $\mathrm{pH}$ 6.8, 5\% (v/v) 2-mercaptoethanol and $10 \%(\mathrm{v} / \mathrm{v})$ glycerol] with a microhomogenizer (Model 226A; As One, Osaka, Japan) in a microfuge tube on ice, followed by boiling for $3 \mathrm{~min}$. A sample obtained from about 5,000 cells in each lane was electrophoresed on a $10 \%$ gel at $150 \mathrm{~V}$, according to the Laemmli method (1970). Gels were stained with $0.2 \%$ Coomassie brilliant blue R250 (CBB R250) dissolved in a stain containing 45\% $(\mathrm{v} / \mathrm{v})$ methanol and $10 \%(\mathrm{v} / \mathrm{v})$ glacial acetic acid, and then destained in a solution containing $27 \%(\mathrm{v} / \mathrm{v})$ methanol and $9 \%(\mathrm{v} / \mathrm{v})$ glacial acetic acid.

\section{Two-dimensional polyacrylamide gel electrophore- sis (2-D PAGE)}

2-D PAGE was performed according to a previously reported method (Sogame et al. 2014b), except that $2 \%$ [v/v] polyoxyethylene (20) sorbitan monooleate [Tween-80; Wako Pure Chemical Industries, Osaka, Japan] was replaced by 4\% (w/v) 3-[(3-Cholamidopropyl)dimethylammonio]propanesulfonate (CHAPS) (Dojindo, Tokyo).

\section{Immunoblotting assay}

Electrophoresed proteins were transferred to an Immobilon-P transfer membrane (Millipore, Bedford, MA, USA) according to a previously reported method (Sogame et al. 2014b). Prior to immunostaining, the blots were blocked for $2-3 \mathrm{~h}$ by soaking in TBST [20 $\mathrm{mM}$ Tris- $\mathrm{HCl}$ ( $\mathrm{pH} 7.2), 150 \mathrm{mM} \mathrm{NaCl}, 0.05 \%$ Tween-20] supplemented with $0.1 \%$ bovine serum albumin (BSA), followed by immunostaining with $1 \mu \mathrm{g} / \mathrm{ml}$ mouse anti-tubulin- $\alpha \mathrm{Ab}-2$ monoclonal antibody (MS-581-Pro; Thermo Scientific, MA, USA) dissolved in a TBST for $40 \mathrm{~min}$ at $37{ }^{\circ} \mathrm{C}$, and then incubation in $0.05 \mu \mathrm{g} / \mathrm{ml}$ HRP-labeled goat anti-mouse IgG (Kirkegaard \& Perry Lab., Gaithersburg, MD, USA) for $40 \mathrm{~min}$ at $37{ }^{\circ} \mathrm{C}$. The antibodies were dissolved in TBST [20 mM Tris- $\mathrm{HCl}$ (pH 8.0), $150 \mathrm{mM} \mathrm{NaCl}, 0.05 \%$ Tween-20] supplemented with $0.1 \%$ BSA.

\section{Detection of phosphorylated proteins}

A complex consisting of biotin-pendant phosphate-binding tag molecule (Phos-tag; $\mathrm{Zn}^{2+}$-Phos-tagTM BTL-104; available at http:www.phos-tag.com) and horseradish peroxidase (HRP)-conjugated streptavidin (GE Healthcare Bio-Sciences, Buckinghamshire, UK) was prepared, and phosphorylated proteins were detected according to the method reported by Kinoshita et al. (2006).

In both immunoblotting and biotinylated Phos-tag/ECL detection assays, the HRP-labeled proteins on the transfer membranes were detected using an enhanced chemiluminescence (ECL) detection system (GE Healthcare). After exposure to Hyperfilm, the blots were stained for 1 min with a $0.1 \%$ CBB R-250 solution containing $40 \%(\mathrm{v} / \mathrm{v})$ methanol and $1 \%$ glacial acetic acid, and then destained in $50 \%(\mathrm{v} / \mathrm{v})$ methanol.

\section{LC-MS/MS analysis}

Prior to liquid chromatography tandem mass spectrometry (LC-MS/MS) analysis, the proteins transferred to the blotting membranes were digested with trypsin (Sigma-Aldrich, St. Louis, MO, USA). The peptides produced by protease digestion were separated by a $0-40 \%$ linear gradient with acetonitrile for $60 \mathrm{~min}$, and then analyzed with a Waters UPLC Xevo Qtof system. Raw data were processed with Waters ProteinLynx Global Server 2.4. Subsequently, protein was identified by searching against the Alveolata protein sequences registered in the NCBIprot database records using a MASCOT search engine (Matrix Science, London, UK).

\section{Electron microscopy}

The electron microscopy procedure for encysting Colpoda cells was performed according to a previously reported method (Funatani et al. 2010). The cells were prefixed with a glutaraldehyde (GA) fixative $[6 \% \mathrm{GA}, 100 \mathrm{mM}$ cacodylate buffer ( $\mathrm{pH} 7.2), 4 \mathrm{mM}$ sucrose] for $6 \mathrm{~h}$, rinsed in $100 \mathrm{mM}$ cacodylate buffer $(\mathrm{pH} 7.2)$, and postfixed in a postfixative $\left[1 \% \mathrm{OsO}_{4}, 100 \mathrm{mM}\right.$ cacodylate buffer $(\mathrm{pH}$ 7.2), $2 \mathrm{mM}$ sucrose] for a week. The postfixed cells were rinsed in distilled water, dehydrated through a graded ethanol series, and finally suspended in acetone. The dehydrated cells were embedded in Spurr's resin. Ultrathin sections were stained with 3\% uranyl acetate and then with lead citrate (10 min each). The sections were observed under a transmission electron microscope (JEOL,1010T).

\section{Visualization of the infraciliature}

In order to visualize the infraciliature, silver carbonate impregnation was performed according to the method reported by Foissner (1993). Prior to silver impregnation, cysts were frozen $\left(-80^{\circ}\right.$ C) and thawed, and then gently homogenized to peel the cyst wall mechanically.

\section{Fluorescence microscopy}

The cells were incubated in PBST [phosphate-buffered saline (PBS) containing $0.05 \%$ Tween-20] for $10 \mathrm{~min}$, and fixed with $3.7 \%$ paraformaldehyde in phosphate-buffered saline (PBS). After 30-min fixation, cells were washed with fresh PBST by centrifugation $(1000 \times \mathrm{g}$ for $30 \mathrm{~s})$ and then incubated in $1 \%$ Nonidet P-40 (NP-40; Sigma-Aldrich) in PBS for $1 \mathrm{~h}$. After washing with PBST by centrifugation $(1000 \times \mathrm{g}$ for $30 \mathrm{~s})$, cells were incubated for $1 \mathrm{~h}$ in PBS containing 1\% bovine serum albumin (BSA; Fujifilm Wako Pure Chemical Corp.), and then incubated for $1 \mathrm{~h}$ with $1 \mu \mathrm{g} /$ $\mathrm{ml}$ anti- $\alpha$-tubulin mouse mAb (Thermo Fisher Scientific, Waltham, MA, USA) at room temperature. The cells were then washed again with PBST by centrifugation $(1000 \times \mathrm{g}$ for $30 \mathrm{~s})$, and incubated for $1 \mathrm{~h}$ with $2 \mu \mathrm{g} / \mathrm{ml}$ goat anti-mouse IgG H\&L (Alexa Fluor ${ }^{\circledR} 488$; Thermo Fisher Scientific) at room temperature. Finally, cells were collected by centrifugation $(1000 \times \mathrm{g}$ for $30 \mathrm{~s})$, washed with PBST, and resuspended in $100 \mathrm{nM}$ Acti-stain ${ }^{\mathrm{TM}} 555$ fluorescent phalloidin (Cytoskeleton, Denver, CO, USA) solution for $30 \mathrm{~min}$ (detection for F-actin; https://en.wikipedia.org/wiki/Phalloidin). The series of 
fixations and staining of cells covered with cyst wall was performed under a vacuum condition $(-760 \mathrm{mHg})$ in order to allow penetration of fixative and probe molecules.

Thus, stained cells were washed with fresh PBS, and observed under a fluorescence microscope (Olympus BX-50) equipped with a green fluorescence filter set (U-MWBV) or a red fluorescence filter set (U-MWIG). When Acti-stain 555 phalloidin fluorescence was observed, excitation light less than $530 \mathrm{~nm}$ was cut off $(<10 \%)$ using a 0-54 filter (Hoya Candeo Optronics, Tokyo) to eliminate FITC fluorescence.

\section{RESULTS}

We analyzed the alteration of water-soluble proteins contained in encysting Colpoda cells by twodimensional polyacrylamide gel electrophoresis (2-D PAGE), and identified proteins whose abundance varied prominently in the encystment process by a liquid chromatography tandem mass spectrometry (MS) analysis. Fig. 1 shows the 2-D PAGE of the water-soluble fraction of encysting cells of C. cucullus Nag-1. Three spots (p56, p37, p19) whose density prominently change during encystment were aligned in Fig. 2. Mass spectrometry (MS) of protein spots revealed that these proteins were $\beta$-tubulin (p56) and its fragments (p37, p19) (Table 1).
If the elevation of tubulin monomers in the watersoluble fraction were due to the disassembly of microtubules, the tubulin content in the water-insoluble fraction would be reduced after encystment induction, and the total tubulin content would be expected not to change. In fact, a previous study (Sogame et al. 2014b) showed that $\alpha$-tubulin content in the water-insoluble fraction ( $\alpha$-tubulin constructing microtubules) was drastically reduced within $12 \mathrm{~h}$ after encystment induction. In addition, immunoblotting assays using anti- $\alpha$ tubulin antibody showed that the total $\alpha$-tubulin content was not reduced much until $12 \mathrm{~h}$ after encystment induction (Fig. 3).

The integrated optical density (IOD) of the spots of $\alpha$-tubulin contained in the water-insoluble fraction (Sogame et al. 2014b) (closed circles), spots of $\beta$-tubulin fragments (p19) contained in the water-soluble fraction (Fig. 2), and total $\alpha$-tubulin bands (immunoblots; Fig. 3) were determined by NIH image analysis (Fig. 4). The results suggest that a temporary assembly of tubulins was slightly promoted within 1-2 h after encystment induction, followed by large-scale disassembly of tubulins.

The vegetative cells of $C$. cucullus Nag-1 were rounded and their cilia gradually shortened in the 2-3 $\mathrm{h}$ after encystment induction (Fig. 5A), followed by an

Table 1. Water-soluble proteins of C. cucullus Nag-1 identified by LC-MS/MS whose amount is uniquely modified by encystment induction

\begin{tabular}{|c|c|c|c|c|}
\hline Proteins & Spots & Sequences of matched peptides [no. of peptides] & Accession no. (organism) & Sequence coverage $(\%)$ \\
\hline$\beta$-tubulin & p56 & $\begin{array}{l}\text { INVYFNEATGGR, GHYTEGAELIDSVLDVVR, } \\
\text { LAVNLIPFPR, } \\
\text { ALTVPELTQQMFDAK, MAVTFIGNSTAIQEMFK [5] }\end{array}$ & $\begin{array}{l}\text { BAG12789.1 (Sorogena } \\
\text { stoianovitchae) }\end{array}$ & $16.7(72 \mathrm{AA} / 432 \mathrm{AA})$ \\
\hline$\beta$-tubulin & p37 & $\begin{array}{l}\text { INVFYNEATGGR, AILMDLEPGTMDSVR, } \\
\text { AGPFGQLFRPDNFVFGQSGAGNNWAK, } \\
\text { GHYTEGAELIDSVLDVVR, } \\
\text { GHYTEGAELIDSVLDVVRK, } \\
\text { EAEGCDCLQGFQITHSLGGGTGSGMGTLLISK, } \\
\text { EEYPDRIMETFSVFPSPK, IMETFSVFPSPK, } \\
\text { FPGQLNSDLR, FPGQLNSDLRK, } \\
\text { LAVNLIPFPR, LHFFMIGFAPLTSR, } \\
\text { ALTVPELTQQMFDAK,YLTACAMFR, } \\
\text { EVDEQMLNVQNK [15] }\end{array}$ & $\begin{array}{l}\text { AHC92551.1 (Colponema } \\
\text { edaphicum) }\end{array}$ & $48.1(194 \mathrm{AA} / 403 \mathrm{AA})$ \\
\hline$\beta$-tubulin & p19 & $\begin{array}{l}\text { FWEVISDEHGIDPTGTYHGDSDLQLER, } \\
\text { INVFYNEATGGR, } \\
\text { AILMDLEPGTMDSVR, } \\
\text { AGPFGQLFRPDNFVFGQTGAGNNWAK, } \\
\text { GHYTEGAELIDSVLDVVR, GHYTEGAELIDSVLDVVRK, } \\
\text { EAEGCDCLQGFQITHSLGGGTGSGMGTLLISK, } \\
\text { EEYPDRIMETFSVFPSPK, IMETFSVFPPK [9] }\end{array}$ & $\begin{array}{l}\text { BAG12789.1 (Sorogena } \\
\text { stoianovitchae) }\end{array}$ & $34.4(149 \mathrm{AA} / 432 \mathrm{AA})$ \\
\hline
\end{tabular}




\section{Acidic}
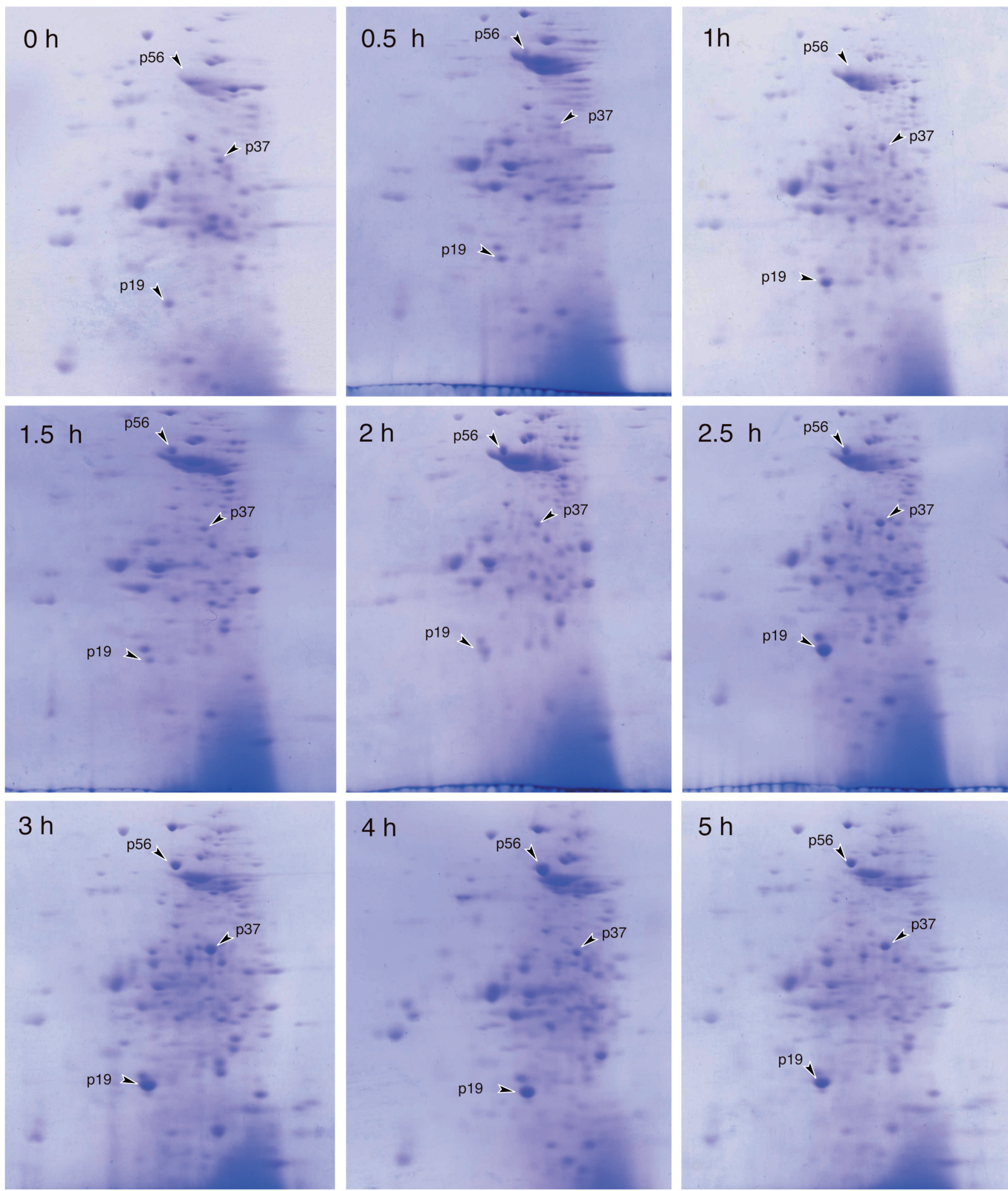

Fig. 1. 2-D PAGE showing an alteration of the water-soluble protein composition at $0 \mathrm{~h}-4$ weeks after the onset of encystment induction of C. cucullus Nag-1. Arrowheads indicate the proteins (p56, p37, p19) whose amount uniquely and markedly changed during resting cyst formation. These proteins were identified as $\beta$-tubulin and its fragments by MS analysis (see Table 1). 
112 Y. Sogame et al.

\section{Acidic}
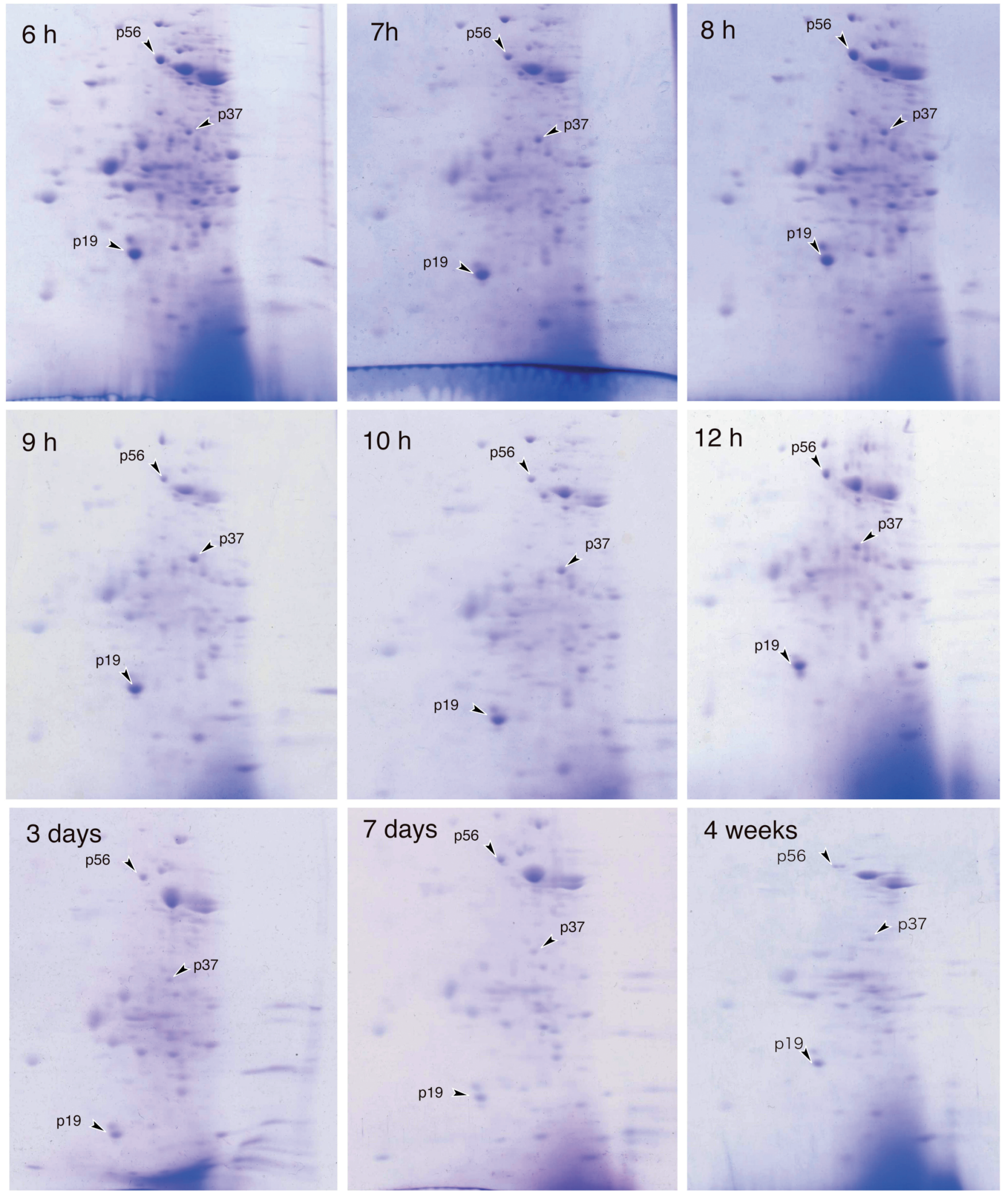

Fig. 1. continued 


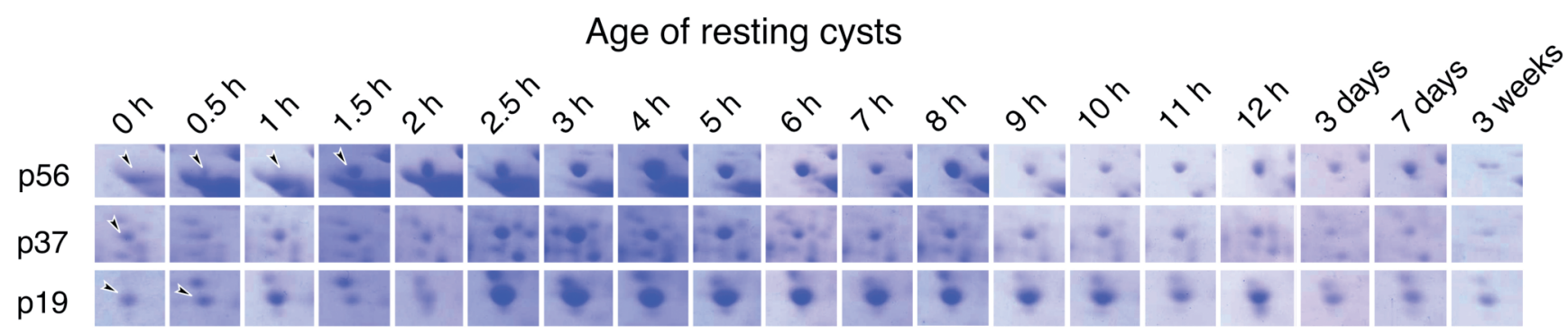

Fig. 2. Changes of the amount of $\beta$-tubulin (p56) and its fragments (p37 and p19) contained in water-soluble fraction during resting cyst formation of C. cucullus Nag-1. Figures above the photographs indicate time lapse after onset of encystment induction.

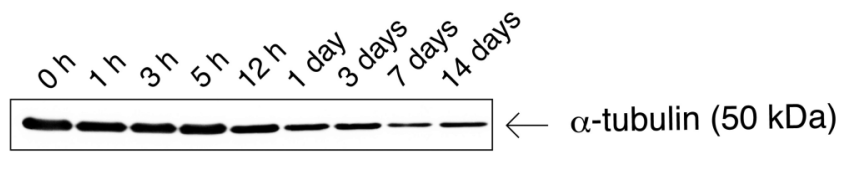

Fig. 3. Immunoblotting assay using anti $\alpha$-tubulin antibody showing total $\alpha$-tubulin content during resting cyst formation of C. cucullus Nag-1. Figures above the photographs indicate time lapse after onset of encystment induction.

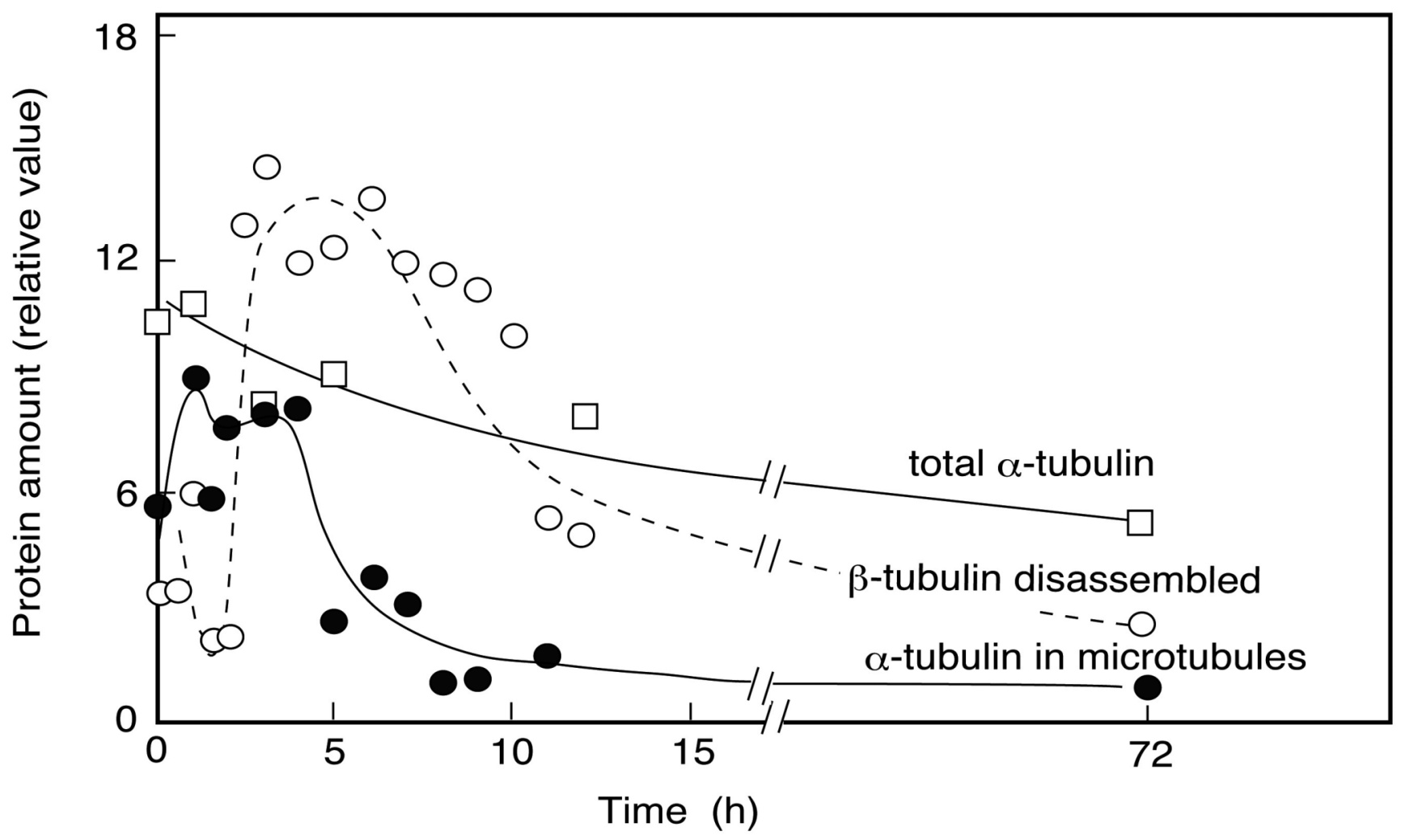

Fig. 4. NIH image analyses of CBB-stained $\alpha$-tubulin spots of gels (closed circles) separated by 2-D PAGE of water-insoluble fraction (Sogame et al. 2014b), CBB-stained $\beta$-tubulin fragment spots of gels (p19 in Fig. 2, open circles) contained in water-soluble fraction, and total $\alpha$-tubulin immunoblotting bands (open squares) (Fig. 3) of C. cucullus Nag-1. Ordinate indicates integrated optical density (IOD) reflecting relative protein amounts. Abscissa indicates the time lapse after onset of encystment induction. 
ectocyst layer formation and withdrawal of cilia inside of ectocyst layer (Fig. 5B).

Fig. 6A shows that the phosphorylation level of $\mathrm{p} 43$ (identified as actin by MS in the study; Sogame et al., 2014a) was elevated just after encystment induction, and continued for several hours. It is known that the phosphorylation of actin is involved in the polymerization or depolymerization of actin filaments (Ohta et al. 1987, Furuhasi and Hatano 1990, Constantin et al. 1998). It is likely that not only microtubules but also actin dynamics may be involved in the early stage of encystment.

If a temporary assembly in cytoplasmic microtubules were required for encystment-dependent cell globulation, which is one of the morphogenetic signs of encysting cells, an inhibitor of tubulin disassembly such as taxol would be expected to promote cell globulation. It is known that taxol completely inhibits disassembly of spindle fiber at $0.15 \mu \mathrm{M}$ (Risinger et al. 2014). When the cells of C. cucullus Nag-1 were induced to encyst in the presence of $10 \mu \mathrm{M}$ taxol, the cell globulation was promoted (Fig. 7A-1). In this case, there was a significant difference at 2.5 and $4 \mathrm{~h}$ ( $\mathrm{p}<0.05$; Mann-Whitney test). The resorption of cilia of encysting cells in the presence of $10 \mu \mathrm{M}$ taxol tended to be slightly suppressed, but there was no significant difference between the positive control group (Fig. 7A-2, Induced without 'Ta') and experimental group (Fig. 7A-2, Induced with 'Ta') ( $p>0.05$, MannWhitney test).

Cytochalasin B (CB) reduces the actin polymerization rate at $2 \mu \mathrm{M}$ by up to $90 \%$ (MacLean-Fletcher and Pollard 1980). When the C. cucullus Nag-1 cells were induced to encyst in the presence of $10 \mu \mathrm{M} \mathrm{CB}$, cell globulation was not suppressed (Fig. 7B-1). The resorption of cilia of encysting cells in the presence of 10 $\mu \mathrm{M}$ CB tended to be slightly suppressed, but there was no significant difference between the control (Fig. 7B2, Induced without ' $\mathrm{CB}$ ') and experimental groups (Fig. 7B-2, Induced with 'CB') ( $\mathrm{p}>0.05$, Mann-Whitney test).
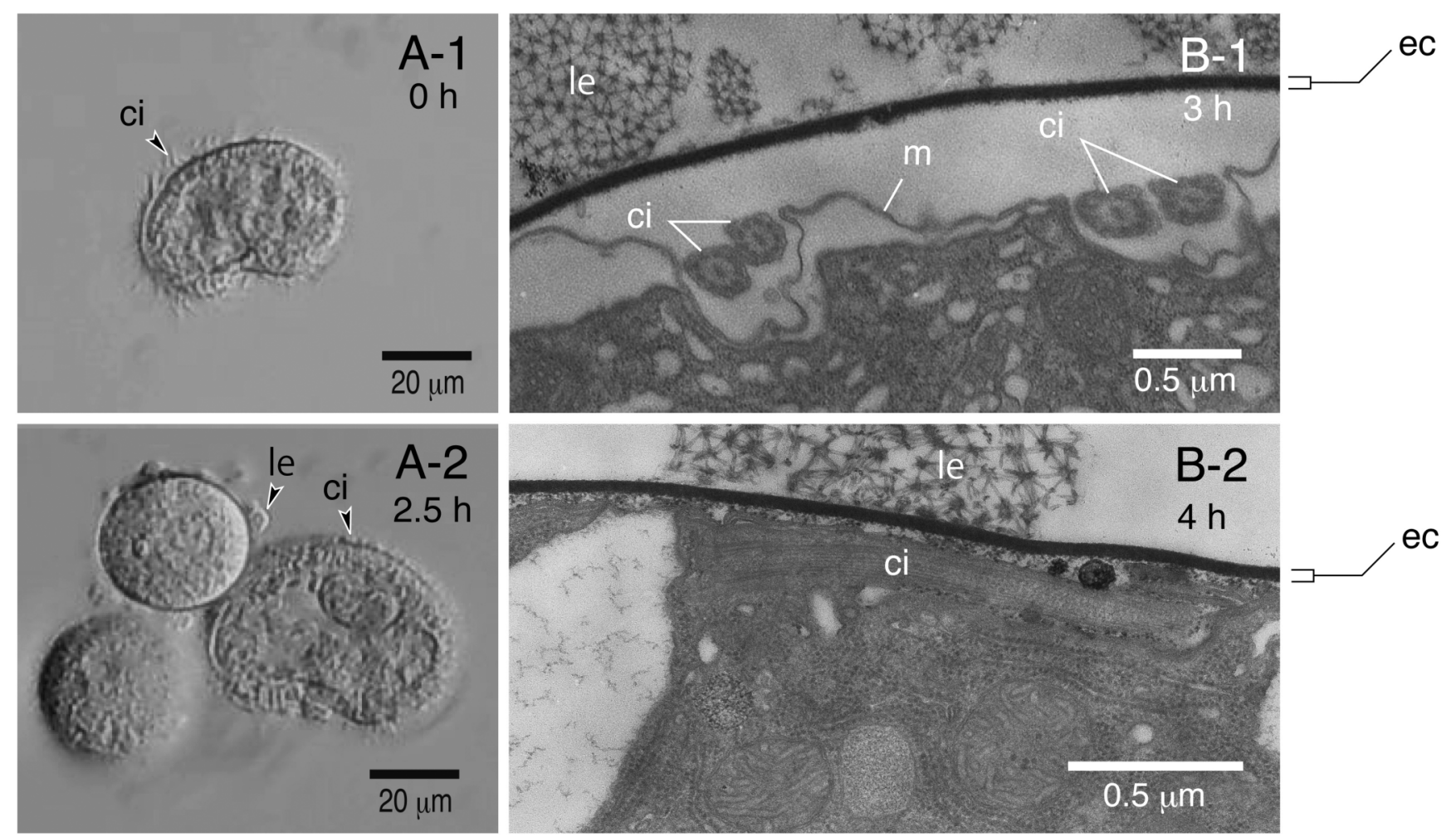

Fig. 5. Photomicrographs (Nomarski images) (A) and transmission electron micrographs (B) of C. cucullus Nag-1 after onset of encystment induction, showing resorption of cilia. (A) Vegetative cell at $0 \mathrm{~h}$ (A-1) and $2.5 \mathrm{~h}$ (A-2) after onset of encystment induction. (B) Encysting 3-h-aged cell (B-1) and 4-h-aged cell (B-2). ci: cilia, m: plasma membrane, ec: ectocyst layer, le: lepidosome. (B-2) a different electron micrograph of the same ultrathin section used in a previous paper (Funatani et al. 2010; Fig. 3). 


\section{$\begin{array}{llllll}0 & 1 & 3 & 5 & 12 & (\mathrm{~h})\end{array}$ \\ (A)

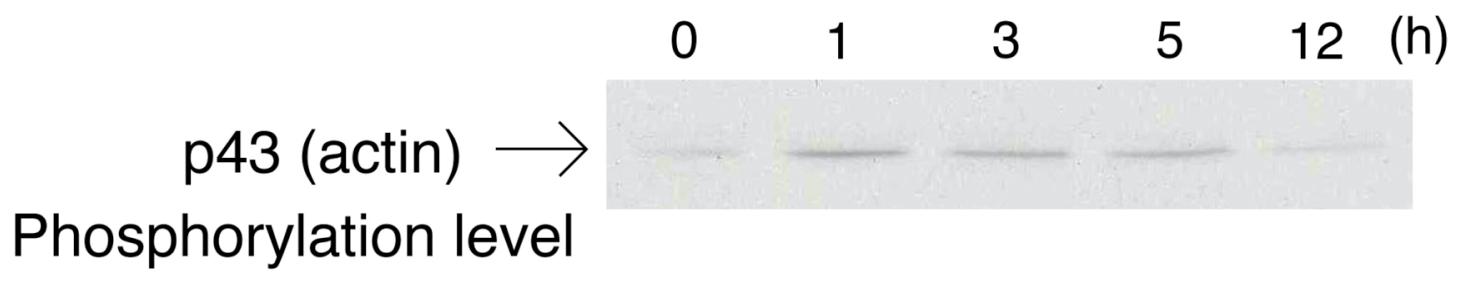

(B)

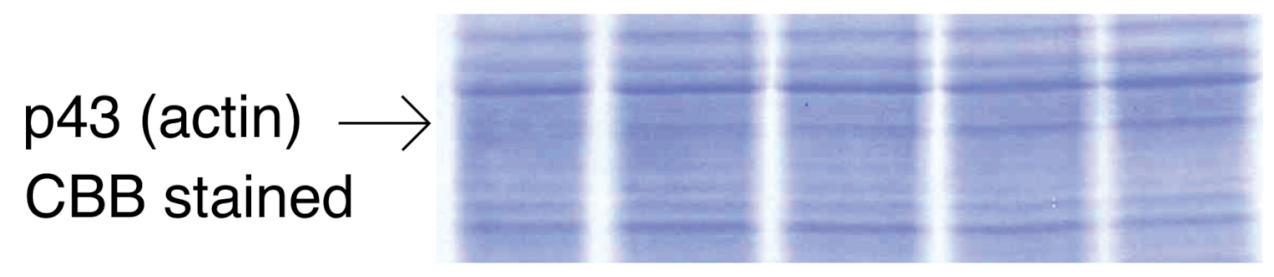

Fig. 6. $\mathrm{Ca}^{2+} /$ overpopulation-stimulated in vivo phosphorylation of 433 (actin, identified by MS) during resting cyst formation of $C$. cucullus Nag-1, detected by biotinylated Phos-tag/ECL assays (A), and blots stained with CBB after the biotinylated Phos-tag/ECL detection (B). Figures above the photographs indicate time lapse after onset of encystment induction.

We tried to visualize microtubule and actin dynamics in the early encystment stages, using FITC-labeled anti$\alpha$-tubulin antibody and Acti-stain 555 phalloidin (red fluorescence for F-actin detection). Fig. 8 shows vegetative cells (A) and encysting cells (B-F) of C. cucullus Nag-1. When the cells stained with both FITC-labeled anti- $\alpha$-tubulin antibody and Acti-stain 555 phaloidin were excited with blue light (400-440 nm), green fluorescence of FITC (detection wavelength: $>475 \mathrm{~nm}$ ) was seen on the cilia (A-C, middle two sets of photographs). In the encysting Colpoda, $1.5 \mathrm{~h}$ after encystment induction, the cilia had begun to shorten, and their distal regions were swollen (Fig. 8B, arrowheads), indicating that axonemal microtubules might be depolymerizing in those distal regions. At $3 \mathrm{~h}$ (Fig. 8C) after encystment induction, cilia could not be detected in the Nomarski images (Fig. 8C, left), because rounded cells were covered with the mucus/lepidosome layer. In this stage, cilia were shortened substantially, and the ciliary rows showed spiral configurations around the oral apparatus (Fig. 8C middle, arrowhead). FITC-labeled microtubules just beneath the plasma membrane were not visualized clearly. The formation of the mucus/lepidosome layer was followed by the formation of the ectocyst layer. It was presumed that in the encysting cells shown in Fig. 8C, the rigid ectocyst layer was not yet complete, because cells still appeared to be fragile. In 3-day-aged cysts (Fig. 8D), FITC fluorescence showing ciliary axonemes was not detected beneath the green autofluores- cent cyst wall (Fig. 8D, ec/en). The basal structure of cilia can still be seen in 3-day-aged cysts (Fig. 8F).

Unfortunately, the present study failed to visualize Acti-stain phalloidin red fluorescence images showing F-actin inside the cilia and cell interior of vegetative and encysting cells (Fig. 8A-D, right). Instead, a vivid red fluorescence was detected on the excreted small globes, which are probably lepidosomes (Fig. 8D, E); the red fluorescence emission of the cyst wall shown in Fig. 8D (right) may be partially attributed to autofluorescence of the endocyst layer. This result suggests that the lepidosomes may contain F-actin. We therefore examined whether lepidosome formation is prevented by $\mathrm{CB}$, but it was not inhibited by $10 \mu \mathrm{M} \mathrm{CB}$ (data not shown).

\section{DISCUSSION}

In a previous study, we showed that $\alpha$-tubulin content in the water-insoluble fraction was drastically reduced within several hours after encystment induction, and interpreted this to mean that the expression level of $\alpha$-tubulin was reduced (Sogame et al. 2014b). In the present study, in contrast, we noticed that $\beta$-tubulin in the water-soluble fraction was promptly elevated in 2.5 $\mathrm{h}$ after encystment induction (Figs. 1, 2, 4), and that total $\alpha$-tubulin content was not so reduced until $12 \mathrm{~h}$ after encystment induction (Figs. 3, 4). Based on these results, we concluded that the tubulin expression level 
$(A-1)$

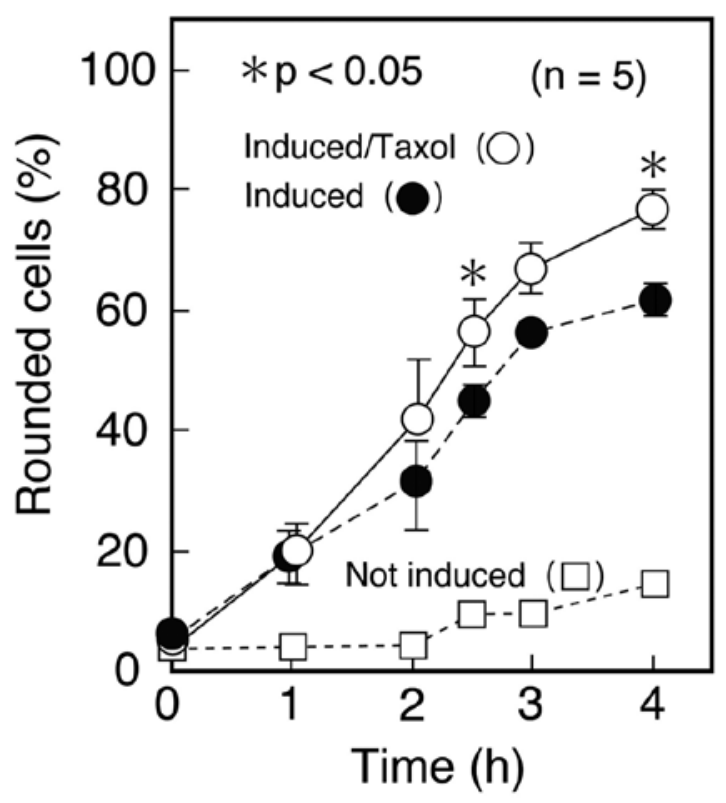

(B-1)

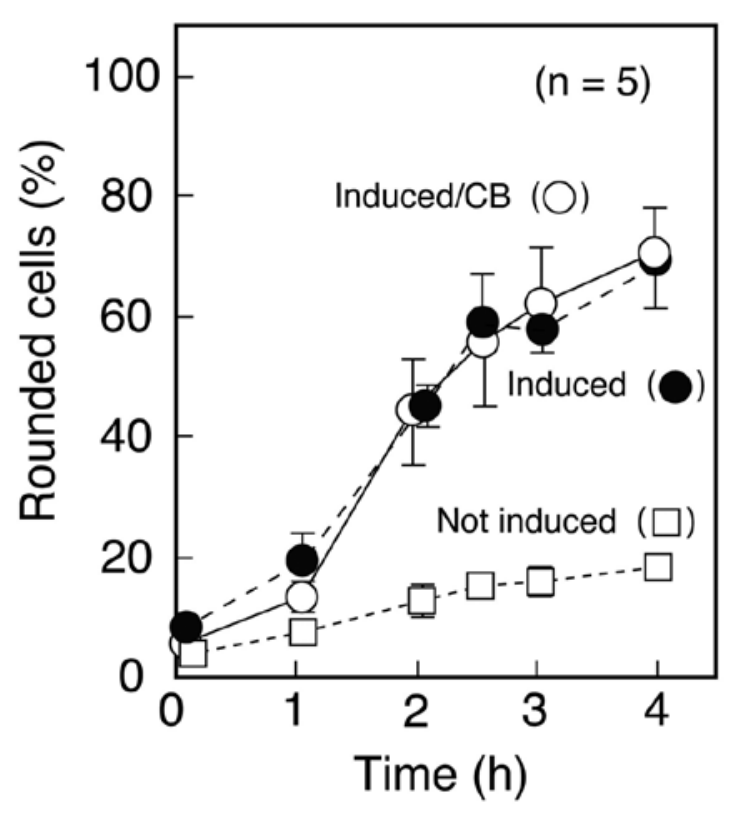

$(\mathrm{A}-2)$

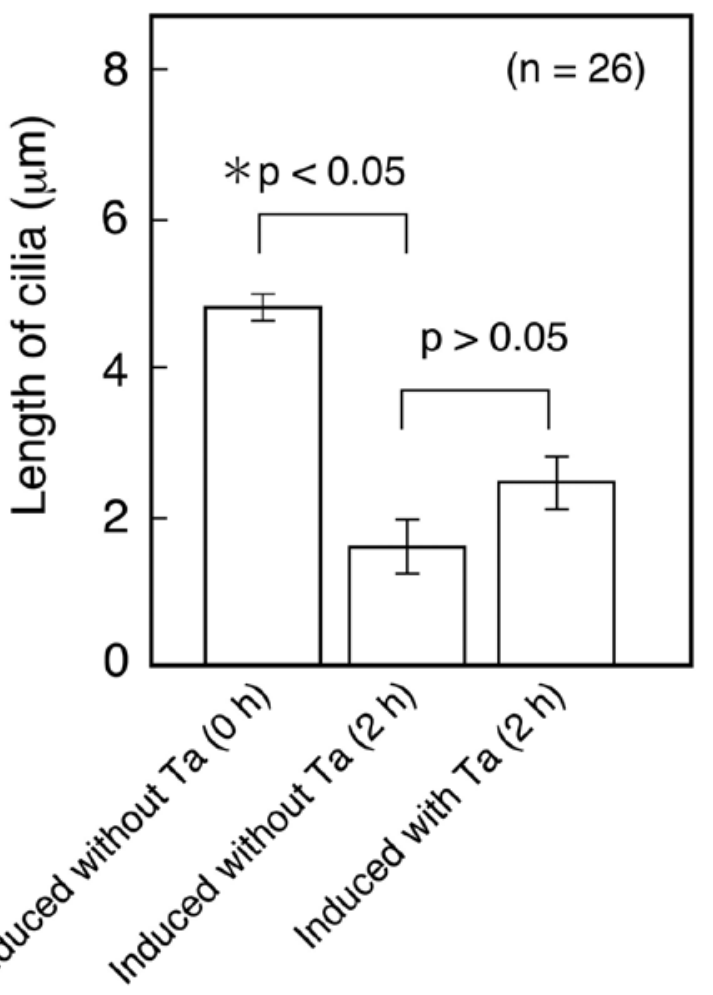

(B-2)

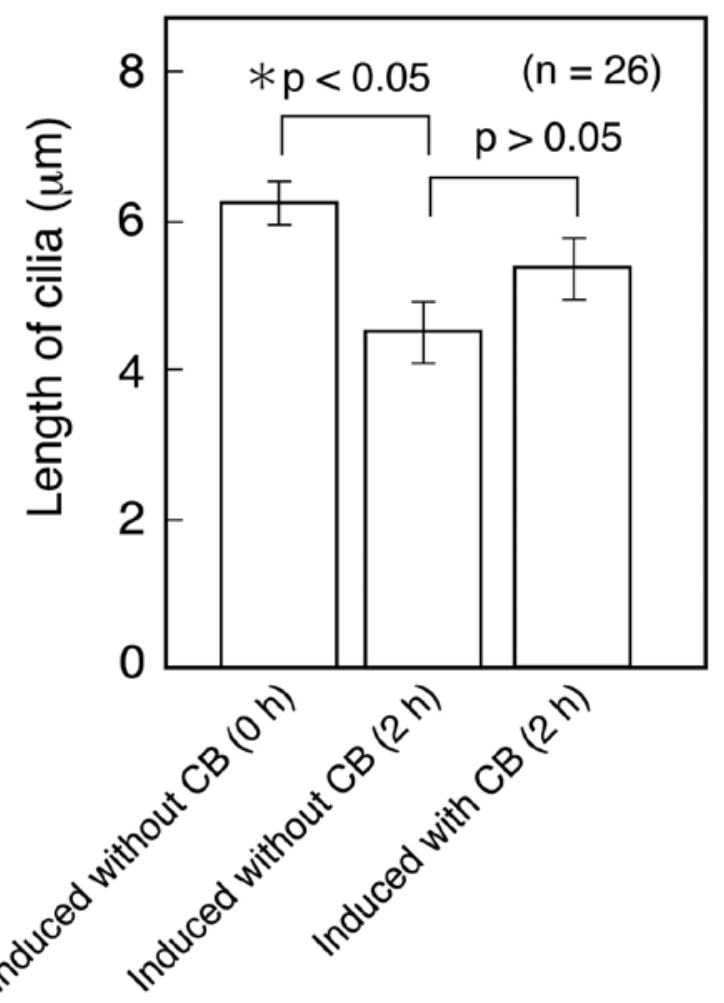


was not reduced by encystment induction, but depolymerization of the microtubules occurred.

Three spots (p56, p37, p19) whose density prominently change during encystment (Figs. 1,2) were identified $\beta$-tubulin (p56) and its fragments (p37, p19) by MS analysis (Table 1). It is known that tubulins have highly reactive sites for proteases, which can thus easily cleave into fragments (Sackett and Wolff 1986). The tubulin fragments (p37 and p19) detected in the present 2-D PAGE were probably produced by endogeneous proteolysis.

In mammal primary cilia, ciliary resorption may be triggered by "decapitation" of the ciliary tip, in which actin filaments play an important role (Phua et al. 2017, Mirvis et al. 2018). It has been reported that the phosphorylation of actin is involved in the polymerization or depolymerization of actin filaments (Ohta et al. 1987, Furuhasi and Hatano 1990, Constantin et al. 1998). Judging from the fact that the phosphorylation level is elevated in cells just after induced encystment in C. cucullus Nag-1 (Fig. 6), it is possible that actin may be involved in the encystment-dependent ciliary resorption. However, cytochalasin B did not suppress the ciliary resorption (Fig. 7B-2), and that no red fluorescent fibril-like images stained with Acti-stain 555 phaloidin were observed in the distal region of cilia (Fig. 8A-C, rightmost lane). These results suggest that actin polymerization in the distal region of cilia may not be responsible for triggering ciliary resorption in $C$. cucullus Nag-1.

New protein synthesis is not required for the cell globulation caused by encystment induction, which is a distinct morphogenetic event in the early stage of
Colpoda encystment (Funadani et al. 2016). Presumably, cytoskeletal dynamics may be involved in such the cell globulation. The present results showed that taxol (an inhibitor of tubulin depolymerization), which promotes assembly of tubulin (Schiff et al. 1979), accelerated the encystment-dependent globulation of the encysting cells of C. cucullus Nag-1 (Fig. 7, A-1). This suggested that an assembly of cytoplasmic microtubules might be involved in cell globulation. The result that a temporary tubulin assembly occurs just after encystment induction (Fig. 4) also supports this idea.

In Entamoeba invadens, globulation during encystment is inhibited by cytochalasin D (an actin polymerization inhibitor), suggesting that actin polymerization may be involved in the encystment-dependent globulation (Herrera-Martínez et al. 2013). On the other hand, the encystment-dependent globulation of C. cucullus Nag-1 cells was not inhibited by cytochalasin B (CB) (Fig. 7B-1). Actin polymerization inhibitors other than CB might need to be tested in C. cucullus Nag-1.

In encysting cells $3 \mathrm{~h}$ after encystment induction, Acti-stain phalloidin red fluorescence was detected in lepidosomes expelled to the extracellular space (Fig. 8D rightmost lane, E). Lepidosomes of C. cucullus Nag-1 are small globules showing a fine fibrous structure (Fig. 5B), and are involved in cell-to-cell or cell-to-substrate adhesion. Lepidosomes contain 45$\mathrm{kDa}$ bacterial elongation factor Tu (EF-Tu) (Funadani et al. 2016). It is also known that in the bacterium $\mathrm{Ba}$ cillus subtilis, EF-Tu interacts and colocalizes with bacterial actin MreB (Defeu Soufo et al. 2010) which is homologous to eukaryotic actins (Jones et al. 2001). Based on this evidence, Acti-stain phalloidin may bind

Fig. 7. Effects of $10 \mu \mathrm{M}$ taxol (A) and $10 \mu \mathrm{M}$ cytochalasin B (B) on $\mathrm{Ca}^{2+} /$ overpopulation-mediated globulation of C. cucullus Nag-1 (A-1, B-1) and ciliary resorption (A-2, B-2). A-1, B-1 - The rate of encysting (rounded) cells was expressed as a percentage of the total number of tested cells (100 randomly selected cells). Open squares (negative control). The cells were suspended in $1 \mathrm{mM} \mathrm{Tris-HCl}(\mathrm{pH} 7.2)$ solution without inhibitors at low cell density $(<2,000 \mathrm{cells} / \mathrm{ml})$. Under this condition, encystment was hardly induced. Closed circles (positive control). The cells were suspended in an encystment-inducing medium [1 mM Tris- $\mathrm{HCl}(\mathrm{pH} 7.2)$ and $\left.0.1 \mathrm{mM} \mathrm{CaCl}_{2}\right]$ without inhibitors at high cell density $\left(>30,000 \mathrm{cell} / \mathrm{s} / \mathrm{ml}\left(\mathrm{Ca}^{2+} /\right.\right.$ overpopulation stimulation). In this condition, the encystment was markedly induced. Open circles (experiment). The cells were suspended in an encystment-inducing medium containing taxol (Ta) or cytochalasin B (CB) at high cell density $(>30,000$ cells $/ \mathrm{ml})$. Points and attached bars correspond to the means of 5 measurements (100 cells per measurement) obtained from different batches and standard errors, respectively.

A-2, B-2 - Length of cilia at $2 \mathrm{~h}$ after onset of encystment induction in the presence or absence of taxol (Ta) or cytochalasin B (CB). In the negative control [Induced without ' $\mathrm{Ta}$ ' $(0 \mathrm{~h})$ or Induced without ' $\mathrm{CB}$ ' $(0 \mathrm{~h})$ ], the cultured cells were collected, then suspended in encystmentinducing medium, and quickly fixed with $3.7 \%$ paraformaldehyde. In the positive control [Induced without 'Ta' $(2 \mathrm{~h})$ or Induced without 'CB' $(2 \mathrm{~h})$ ], the cells were suspended for $2 \mathrm{~h}$ in an encystment-inducing medium without inhibitors at high cell density (>30,000 cells/ml), and then fixed with 3.7\% paraformaldehyde. In the experimental groups [Induced with 'Ta' $(2 \mathrm{~h})$ or Induced with 'CB' $(2 \mathrm{~h})$ ], the cells were suspended for $2 \mathrm{~h}$ in an encystment-inducing medium containing inhibitors at high cell density (>30,000 cells $/ \mathrm{ml})$, and then fixed with $3.7 \%$ paraformaldehyde. Columns and attached bars correspond to the means in 26 cells and standard errors, respectively. 


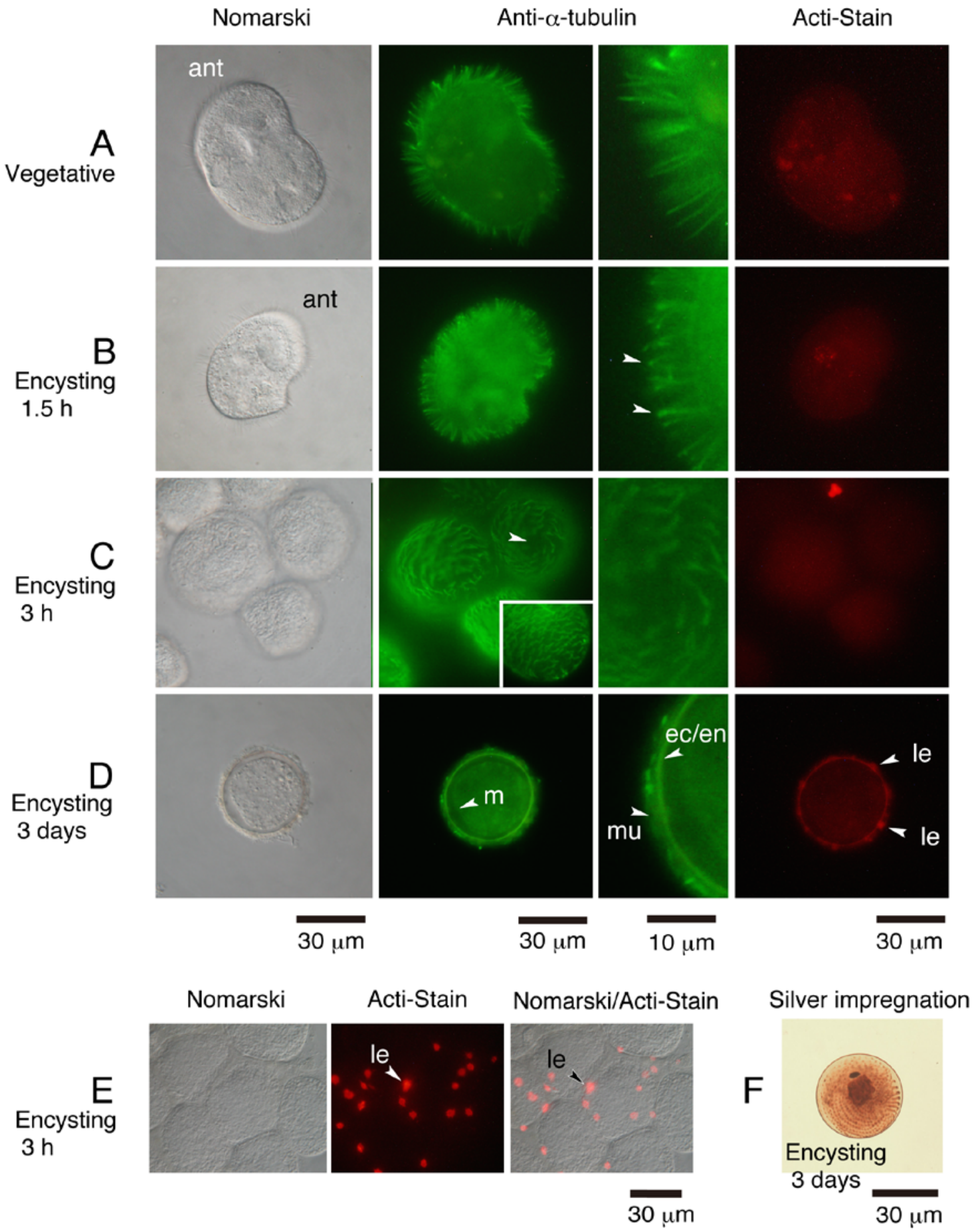

Fig. 8. A-D - Nomarski (leftmost lane), FITC-immunofluorescence images labeled with anti- $\alpha$-tubulin monoclonal antibody and their magnified images (middle two lanes), and red fluorescence images (rightmost lane) stained with Acti-stain 555 phalloidin (detection for F-actin) of encysting cells of $C$. cucullus Nag-1. Each set of photomicrographs arranged in a horizontal row shows an identical cell except for Fig. 8C (FITC image, inset). A - Vegetative cell. B-D - Encysting cells of C. cucullus Nag-1 at $1.5 \mathrm{~h}$ (B), 3 h (C) and 3 days (D) after encystment induction. E - Nomarski image (left), red fluorescence images (middle) stained with Acti-stain 555 phalloidin, and a Nomarski image superimposed with a red fluorescence image obtained by Acti-stain 555 phalloidin staining (right) in encysting cells of $C$. cucullus Nag-1 at $3 \mathrm{~h}$ after encystment induction. F - Silver impregnation of a 3-day-aged cyst showing the basal structure of cilia. This photograph was reproduced from our previous work (Watoh et al. 2005, Fig. 9b). ant: anterior end, le: lepidosome, mu: mucus layer, ec/en: ectocyst layer lined with endocyst layer, m: plasma membrane. B - arrowheads: swollen tip of cilia. C - arrowhead: oral apparatus. 
to the actin-like filaments constructing the lepidosomes of Colpoda, which possibly interact with colocalizing $\mathrm{EF}-\mathrm{Tu}$. The result that lepidosome formation was not inhibited by CB (an inhibitor for eukaryotic actin polymerization) suggests that $\mathrm{CB}$ may not bind to actinlike filaments contained in lepidosomes of Colpoda.

In the resting cysts of ciliate Euplotes encysticus, the ciliary axonemes and ciliature base-associated microtubules are visualized by FLUTAX fluorescent labeling method, showing that such microtubule networks still remain in the resting cysts (Chen et al. 2014). On the other hand, in 3-day-aged C. cucullus Nag-1 resting cysts, FITC fluorescence of ciliary axonemes and subpellicular microtubule network was not detected (Fig. 8D). Presumably the microtubule network may be disintegrated. This result is consistent with biochemical assays showing that tubulin disassembly is completed around 3 days after encystment induction (Figs. 2, 4). Unfortunately, microtubule dynamics failed to be clearly traced, because the mucus layer covering Colpoda cells may disturb the diffusion of anti- $\alpha$-tubulin antibody into cell interior.

In the present study, encystment-dependent microtubule dynamics in C. cucullus Nag-1 was revealed by means of 2-D PAGE and MS analyses, and its roles were discussed. Further studies to clearly visualize cytoskeletal dynamics including actin would be needed. The basal structure of cilia remained in 3-day-aged cysts (Fig. 8F). It is desired to clarify whether or not such a basal structure remains in matured cysts aged more than 1 week.

Acknowledgment. The electron micrographs were kindly provided by Dr. Akemi Kida. This research was financially supported by a Sasagawa Scientific Research Grant (\#24-407) from the Japan Science Society, by a Research Fellowship of the Japan Society for the Promotion of Science for Young Scientists (\#13J08784), and by a Grant-in-Aid for Scientific Research (B) (\#19H03447).

\section{REFERENCES}

Asami H., Ohtani Y., Iino R., Sogame Y., Matsuoka T. (2010) Behavior and $\mathrm{Ca}^{2+}$-induced cell signaling for encystment of Colpoda cucullus. J. Protozool. Res. 20: 1-6

Chen J., Gao X., Wang B., Chen F., Wu N., Zhang Y. (2014) Proteomic approach to reveal the proteins associated with encystment of the ciliate Euplotes encysticus. PLOS ONE e97362

Constantin B., Meerschaert K., Vandekerckhove J., Gettemans J. (1998) Disruption of the actin cytoskeleton of mammalian cells by the capping complex actin-fragmin is inhibited by actin phosphorylation and regulated by $\mathrm{Ca}^{2+}$ ions. J. Cell Sci. 111: 1695-1706

Defeu Soufo H. J., Reimold C., Linne U., Knust T., Gescher J., Graumann P. L. (2010) Bacterial translation elongation factor
EF-Tu interacts and colocalizes with actin-like MreB protein. Proc. Natl. Acad. Sci. (USA) 107: 3163-3168

Foissner W. (1993) Colpodea (Ciliophora). Gustav Fischer Verlag, Stuttgart

Foissner W., Stoeck T, Agatha S., Dunthorn M. (2011) Intraclass evolution and classification of the Colpodea (Ciliophora). J. Eukaryot. Microbiol. 58: 397-415

Funadani R., Sogame Y., Kojima K., Takeshita T., Yamamoto K., Tsujizono T., Suizu F., Miyata S., Yagyu K., Suzuki T., Arikawa M., Matsuoka T. (2016) Morphogenetic and molecular analyses of cyst wall components in the ciliated protozoan Colpoda cucullus Nag-1. FEMS Microbiol. Lett. 363: fnw203

Funatani R., Kida A., Watoh T., Matsuoka T. (2010) Morphological events during resting cyst formation (encystment) in the ciliated protozoan Colpoda cucullus. Protistology 6: 204-217.

Furuhasi K., Hatano S. (1990) Control of actin filament length by phosphorylation of fragmin-actin complex. J. Cell Biol. 111: 1081-1087

Jiang C., Wei W., Yan G., Shi T., Miao W. (2019) Transcriptome analysis reveals the molecular mechanism of resting cyst formation in Colpoda aspera. J. Eukaryot. Microbiol. 66: 212-220

Jones J. F., Carballido-López R., Errington J. (2001) Control of cell shape in bacteria: Helical, actin-like filaments in Bacillus subtilis. Cell 104: 913-922

Herrera-Martínez M., Hernández-Ramírez V. I., Lagunes-Guillén A. E., Chávez-Munguía B., Talamás-Rohana P. (2013) Actin, RhoA, and Rab11 participation during encystment in Entamoeba invadens. BioMed Res. Int. 2013: 919345

Kinoshita E., Kinoshita-Kikuta E., Takiyama K., Koike T. (2006) Phosphate-binding tag: A new tool to visualized phosphorylated proteins. Mol. Cell. Proteomics 5: 749-757

Laemmli U. (1970) Cleavage of structural proteins during the assembly of the head of bacteriophage T4. Nature 227: 680-685

MacLean-Fletcher S., Pollard T. D. (1980) Mechanism of action of cytochalasin B on actin. Cell 20: 329-341

Maeda H., Akematsu T., Fukui R., Matsuoka T. (2005) Studies on the resting cyst of ciliated protozoan Colpoda cucullus: Resistance to temperature and additional inducing factors for en-or excystment. J. Protozool. Res. 15: 7-13

Matsuoka K., Funadani R., Matsuoka T. (2017) Tolerance of Colpoda cucullus resting cysts to ultraviolet irradiation. J. Protozool. Res. 27: 1-7

Matsuoka T., Kondoh A., Sabashi K., Nagano N., Akematsu T., Kida A., Iino R. (2009) Role of $\mathrm{Ca}^{2+}$ and cAMP in a cell signaling pathway for resting cyst formation of ciliated protozoan Colpoda cucullus. Protistology 6: 103-110

Mirvis M., Stearns T., Nelson W. J. (2018) Cilium structure, assembly, and disassembly regulated by the cytoskeleton. Biochem. J. 475: 2329-2353

Müller H., Achilles-Day U. E. M., Day J. G. (2010) Tolerance of the resting cysts of Colpoda inflata (Ciliophora, Colpodea) and $\mathrm{Me}$ seres corlissi (Ciliophora, Spirotrichea) to desiccation and freezing. Eur. J. Protistol. 46: 133-142

Ohta Y., Akiyama T., Nishida E., Sakai H. (1987) Protein kinase $\mathrm{C}$ and cAMP-dependent protein kinase induce opposite effects on actin polymerizability. FEBS Lett. 222: 305-310

Pan N., Niu T., Bhatti M. Z., Zhang H., Fan X., Ni B., Chen J. (2019) Novel insights into molecular mechanisms of Pseudourostyla cristata encystment using comparative transcriptomics. Sci. Rep. 9: 19109

Phua S. C., Chiba S., Suzuki M., Su E., Roberson E. C., Pusapati G. V., Setou M., Rohatgi R., Reiter J. F., Ikegami K., Inoue T. 
(2017) Dynamic remodeling of membrane composition drives cell cycle through primary cilia excision. Cell 168: 264-279, e15

Risinger A. L., Riffle S. M., Lopus M., Jordan M. A., Wilson L., Mooberry S. L. (2014) The taccalonolides and paclitaxel cause distinct effects on microtubule dynamics and aster formation. Mol. Cancer 28: 13-41

Sackett D. L., Wolff J. (1986) Proteolysis of tubulin and the substructure of the tubulin dimer. J. Biol. Chem. 261: 9070-9076

Schiff P. B., Fant J., Horwitz S. B. (1979) Promotion of microtubule assembly in vitro by taxol. Nature 277: 665-667

Sogame Y., Kida A., Matsuoka T. (2011a) Possible involvement of endocyst in tolerance of the resting cyst of Colpoda cucullus against HCl. African J. Microbiol. Res. 5: 4316-4320

Sogame Y., Kinoshita E., Matsuoka T. (2011b) $\mathrm{Ca}^{2+}$-dependent in vivo protein phosphorylation and encystment induction in the ciliated protozoan Colpoda cucullus. Eur. J. Protistol. 47: 208-213

Sogame Y., Kojima K., Takeshita T., Kinoshita E., Matsuoka T. (2012) EF-1 $\alpha$ and mitochondrial ATP synthase $\beta$ chain: Alteration of their expression in encystment-induced Colpoda cucullus. J. Euk. Microbiol. 59: 401-406
Sogame Y., Kojima K., Takeshita T., Kinoshita E., Matsuoka T. (2014a) Identification of cAMP-dependent phosphorylated proteins involved in the formation of environment-resistant resting cysts by the terrestrial ciliate Colpoda cucullus. Inv. Surv. J. 11: 213-218

Sogame Y., Kojima K., Takeshita T., Kinoshita E., Matsuoka T. (2014b) Identification of differentially expressed water-insoluble proteins in the encystment process of Colpoda cucullus by two-dimensional electrophoresis and LC-MS/MS analysis. $J$. Eukariot. Microbiol. 61: 51-60

Sogame Y., Matsuoka T. (2013) Evaluation of intracellular $\mathrm{Ca}^{2+}$ concentration by fura 2 ratiometry in encystment-induced Colpoda cucullus. Acta Protozool. 52: 51-54

Taylor C. V., Strickland A. G. R. (1936) Effects of high vacua and extreme temperatures on the cysts of Colpoda cucullus. Physiol. Zool. 9: 15-26

Watoh T., Sekida S., Yamamoto K., Kida A., Matsuoka T. (2005) Morphological study on the encystment of the ciliated protozoan Colpoda cucullus. J. Protozool. Res. 15: 20-28

Received on 22 ${ }^{\text {nd }}$ April, 2020; revised on $10^{\text {th }}$ July, 2020; accepted on $5^{\text {th }}$ August, 2020 